\title{
PENINGKATAN KETERAMPILAN MENULIS KARANGAN NARASI MELALUI METODE MIND MAPPING PADA SISWA KELAS V SD
}

\author{
Tri Puji Lestari \\ Universitas PGRI Semarang \\ e-mail: tripuji.lestari73@yahoo.co.id \\ Artikel diterima: 23 Agustus 2018; disetujui: 31 Mei 2019

\begin{abstract}
The purpose of this study is to improve the writing skills of fifth grade students at Pulorejo 01 Elementary School in Pati in Indonesian Language learning of writing narrative essays aspects using the mind mapping method. This study uses a type of classroom action research with 2 cycles. The subjects of this study were 23 students. The results showed an increase in narrative writing skills using the mind mapping method which was shown by increasing the score according to the KKM in the first cycle of $4 \%$ and in the second cycle reaching $44 \%$.
\end{abstract}

Keywords: mind mapping, writing skills, narrative essays, elementary school

\begin{abstract}
Abstrak: Tujuan penelitian ini yaitu untuk meningkatkan keterampilan menulis siswa kelas V SD Negeri Pulorejo 01 Pati dalam pembelajaran Bahasa Indonesia aspek menulis karangan narasi dengan menggunakan metode mind mapping. Penelitian ini menggunakan jenis penelitian tindakan kelas dengan 2 siklus. Subyek penelitian ini berjumlah 23 siswa. Hasil penelitian menunjukkan peningkatan keterampilan menulis narasi dengan menggunakan metode mind mapping yang ditunjukkan dengan peningkatan skor sesuai KKM di siklus I sebesar $4 \%$ dan di siklus II mencapai $44 \%$.
\end{abstract}

Kata Kunci: mind mapping, keterampilan menulis, karangan narasi, sekolah dasar

Pendidikan sangat penting diperoleh setiap warga Negara untuk menciptakan bangsa Indonesia sesuai dengan UUD 1945. Undang-Undang RI No. 20 tahun 2003 tentang Sistem Pendidikan Nasional bab IV pasal 5 ayat 1 bahwa setiap warga negara mempunyai hak yang sama untuk memperoleh pendidikan yang bermutu. Berdasarkan landasan hukum tersebut dapat disimpulkan bahwa setiap warga wajib memperoleh pendidikan untuk mengembangkan bangsa. Upaya yang dapat dilakukan terkait hal tersebut adalah dengan mempelajari bahasa karena sesungguhnya bahasa merupakan produk kebudayaan. Salah satu mata pelajaran yang wajib dipelajari oleh warga Indonesia adalah Bahasa Indonesia. Hal tersebut sebagaimana tertuang dalam enurut Permendiknas nomor 22 tahun 2006 yang tercantum dalam standar isi mata pelajaran Bahasa Indonesia merupakan salah satu mata pelajaran yang diharapkan membantu peserta didik mengenal dirinya, budayanya, dan budaya orang lain.

Bahasa Indonesia merupakan bahasa pengantar resmi dalam pendidikan yang mempunyai kedudukan penting dalam dunia pendidikan. Pada jenjang sekolah dasar, siswa mempelajari berbagai keterampilan berbahasa dalam pembelajaran Bahasa Indonesia. Menurut Tarigan (2008), keterampilan berbahasa terdiri dari empat aspek yaitu: (1) menyimak, (2) berbicara, (3) membaca, (4) menulis. Keempat keterampilan tersebut saling berhubungan dan berkaitan satu sama lain. Salah satu keterampilan berbahasa yang harus dikuasai siswa adalah keterampilan menulis.

Keterampilan menulis dipelajari setiap siswa pada setiap jenjang pendidikan, mulai tingkat 
prasekolah hingga perguruan tinggi. Bahkan dalam kehidupan sehari-hari, setiap orang tidak terlepas dari kegiatan menulis. Salah satu aspek menulis adalah menulis paragraf narasi. Dengan menulis seseorang dapat mengungkapkan pikiran dan gagasan untuk mencapai maksud dan tujuan. Menurut Tarigan (2008) menulis ialah menurunkan atau melukiskan lambang-lambang grafik yang menggambarkan suatu bahasa yang dipahami oleh seseorang, sehingga orang-orang lain dapat membaca lambang-lambang grafik tersebut kalau mereka memahami bahasa dan gambaran grafik itu.

Menulis merupakan suatu kegiatan yang produktif dan ekspresif. Dalam kegiatan menulis, penulis haruslah terampil memanfaatkan struktur bahasa dan kosa kata. Akan tetapi dalam pembelajaran bahasa Indonesia, hal ini merupakan salah satu kesulitan yang dialami siswa, terlebih lagi menulis narasi. Permasalahan utama yang dihadapi siswa dalam menulis narasi yaitu ketidakcukupan kemampuan dalam menggagas ide yang selanjutnya siswa kesulitan untuk mengembangkan paragraf yang sesuai dengan topik-topik yang ingin dijabarkan (Yunus dan Chien, 2016).

Narasi sendiri secara sederhana merupakan sebuah bentuk penceritaan kembali (Huy, 2015). Lebih spesifik, menurut Keraf (2010:136) narasi adalah suatu bentuk wacana yang berusaha menggambarkan dengan sejelas-jelasnya kepada para pembaca suatu peristiwa yang telah terjadi. Ada dua jenis bentuk narasi yaitu (1) narasi ekspositoris dan nararsi sugestif. Narasi ekspositoris merupakan jenis narasi yang menggambarkan rangkaian perbuatan secara informatif dengan tujuan memberi pengetahuan (Martavia, 2016). Adapun narasi sugestif merupakan narasi yang menggambarkan rangkaian perbuatan dengan tujuan merangsang daya khayal/imajinasi pembaca. Adapun contoh Contoh narasi ekspositoris antara lain biografi atau kisah pengalaman, sedangkan contoh narasi sugestif antara lain novel dan cerpen (Riana \& Setiadi, 2017).

Dalam aplikasi teoritis didasarkan dari tuntutan kurikulum nasional Indonesia, siswa diharuskan mempelajari semua keterampilan berbahasa, termasuk juga keterampilan menulis narasi. Pada kenyataannya, fakta menunjukkan bahwa keterampilan menulis narasi siswa masih belum terbangun maksimal khususnya di kelas V SDN Pulorejo 01 Pati yang dilakukan pada tanggal 29 Oktober 2016 berdasarkan wawancara dan observasi. Sekolah dasar tersebut menggunakan Kurikulum
Tingkat Satuan Pendidikan (KTSP) dengan jumlah peserta didik 23 siswa yang terdiri dari 11 siswa lakilaki dan 12 siswa perempuan. Pada kenyataannya siswa di sekolah tersebut kurang terampil dalam menulis karangan narasi pada pembelajaran Bahasa Indonesia. Hal ini dibuktikan dengan adanya 9 dari 23 siswa yang masih kurang bisa memilih kalimat untuk dikembangkan, kerapian penulisan, ketepatan menyusun cerita agar menjadi runtut, menyusun ejaan dengan benar, dan penggunaan kata yang belum tepat. Hal tersebut juga didukung oleh data hasil belajar siswa yang menunjukkan banyak siswa memperoleh nilai di bawah Kriteria Ketuntasan Minimum (KKM) yaitu 75. Terlebih lagi, pada kegiatan observasi juga diperoleh data bahwa siswa hanya berkonsentrasi di awal saja dan selebihnya siswa merasa jenuh dengan pembelajaran yang hanya berpusat pada ceramah guru, sehingga membuat siswa menjadi kurang antusias.

Berdasarkan fakta tersebut, diperlukan proses belajar berlanjut sehingga aspek kebahasaan yang dimiliki siswa lebih mudah diterapkan. Hal tersebut sebagaimana yang ditekankan pada Peraturan Menteri Pendidikan Nasional (Permendiknas) Nomor 41 tahun 2007 bahwa pembelajaran merupakan proses yang melibatkan keaktifan siswa sehingga pembelajaran berpusat pada peserta didik yang membangkitkan motivasi belajar siswa. Permasalahan yang timbul dari siswa yaitu kurangnya melatih keterampilan menulis dan motivasi belajar yang rendah sehingga aktivitas siswa dalam belajar kurang maksimal. Hal tersebut yang mengakibatkan siswa malas untuk menulis, di samping permasalahan ketidakpahaman unsur gramatikal dan pilihan kata (Huy, 2015). Oleh sebab itu, diperlukan sebuah upaya agar siswa menyadari bahwa menulis adalah suatu keterampilan mutlak yang harus diperlukan untuk mencapai kesuksesan dalam kehidupan.

Upaya untuk mengatasi permasalahan dalam penelitian ini yaitu dengan penggunaan metode pembelajaran yang dapat menarik perhatian siswa dan meningkatkan kemampuan menulis narasi siswa kelas V SDN Pulorejo 01 Pati yaitu variasi metode pembelajaran dengan mind mapping. Menurut Buzan (dalam Kurniawati, 2010) mind mapping merupakan cara mencatat yang kreatif, efektif dan secara harfiah akan memetakan pikiranpikiran. Mind mapping juga merupakan peta rute yang memudahkan ingatan dan memungkinkan untuk menyusun fakta dan pikiran, dengan demikian cara kerja alami otak dilibatkan sejak 
awal (Buzan, 2010). Selain itu, dengan penggunaan karakteristik-karakteristik unik yang bercabang, hal ini diasumsikan menjadi komponen yang menarik minat siswa (Subandi, dkk, 2018). Hal ini juga dapat disimpulkan bahwa dengan penggunaan mind mapping proses mengingat informasi akan lebih mudah dan lebih bisa diandalkan daripada menggunakan teknik mencatat tradisional.

Penelitian ini didukung oleh beberapa penelitian terdahulu terkait dengan efektifitas penggunaan mind mapping dalam pembelajaran. Hasil penelitian yang dilakukan oleh Sulistiyaningsih (2010) menunjukkan adanya peningkatan keterampilan menulis narasi dengan menggunakan metode mind mapping dengan deskripsi nilai sebagai berikut: (1) rata-rata keterampilan menulis narasi pada pratindakan yaitu 61,2 termasuk kategori kurang cukup, (2) siklus I menunjukkan perubahan dari 61,2 menjadi 65,8 termasuk kategori cukup, dan (3) siklus II meningkat dari 65,8 menjadi 73,4 termasuk kategori baik. Selanjutnya yaitu hasil penelitian Dewi (2010) yang menunjukkan adanya kesamaan terkait peningkatan keterampilan menulis dengan menggunakan metode mind mapping. Hal tersebut ditunjukkan dengan hasil tes pada siklus I diperoleh nilai persentase sebesar $40 \%$, siklus II sebesar $72 \%$, dan siklus III sebesar $88 \%$ sehingga disimpulkan bahwa penggunaan metode mind mapping dapat meningkatkan kemampuan menulis karangan narasi siswa.

Dengan menggunakan penelitian tindakan kelas diharapkan dapat memperbaiki atau meningkatkan kualitas pembelajaran yang dilakukan oleh guru di dalam kelas melalui refleksi diri, dengan tujuan untuk memperbaiki kinerja guru sehingga hasil belajar siswa dapat meningkat. Pemilihan metode pembelajaran mind mapping diharapkan dapat mengajak siswa untuk berperan aktif terhadap proses belajar mengajar yang diberikan, melatih kekompakan peserta didik, serta melatih siswa untuk menuliskan isi ataupun membagikan idenya terhadap teman sekelas. Berdasarkan latar belakang di atas, maka tujuan penelitian ini yaitu untuk meningkatkan keterampilan menulis siswa kelas V SD Negeri Pulorejo 01 Pati dalam pembelajaran Bahasa Indonesia aspek menulis karangan narasi dengan menggunakan metode mind mapping.

\section{METODE}

Penelitian ini menggunakan desain penelitian tindakan kelas (PTK) yang terbagi dalam dua siklus, yaitu proses tindakan pada siklus 1 dan siklus 2. Pada setiap siklus dilakukan empat tahap, empat tahap ini adalah perencanaan, tindakan, pengamatan, dan refleksi (Arikunto, dkk., 2012). Tempat dilaksanakan penelitian ini yaitu di SD Negeri Pulorejo 01 Kabupaten Pati. Penelitian dilaksanakan pada semester genap Tahun Pelajaran 2016/2017 yang dilaksanakan dalam 2 siklus selama 1 minggu pada bulan Mei 2017. Subyek yang diteliti dalam penelitian ini adalah siswa kelas V SD Negeri Pulorejo 01 Pati dengan jumlah murid adalah 23 siswa yang terdiri dari 11 siswa laki-laki dan 12 siswa perempuan.

Penelitian tindakan kelas ini dilakukan oleh peneliti dengan berkolaborasi dengan guru kelas $\mathrm{V}$ SD Negeri Pulorejo 01. Peneliti sebagai pengamat ketika penelitian ini berlangsung di kelas $\mathrm{V}$ SD Negeri 01 dan Ibu P selaku guru kelas V SD Negeri Pulorejo 01 sebagai pengajar dalam proses pembelajaran ketika penelitian berlangsung.

Pembelajaran yang dilakukan pada siklus 1 dan siklus 2 memiliki tujuan yang berbeda. Siklus 1 dilakukan dengan tujuan untuk mengetahui keterampilan siswa dalam menulis karangan narasi, sedangkan pada hasil penelitian yang dilaksanakan pada siklus 2 bertujuan untuk mengetahui kemampuan siswa dalam menulis karangan narasi setelah dilakukan perbaikan dalam proses belajar mengajar siswa yang disadarkan pada refleksi 1 . pengumpulan data dalam penelitian ini meliputi observasi, dokumentasi, dan tes. Dalam penelitian ini, teknik analisis data yang digunakan diarahkan untuk menjawab rumusan masalah atau menguji hipotesis yang telah dirumuskan (Arikunto, 2010).

\section{HASIL}

Penelitian tindakan kelas ini dilaksanakan dalam dua siklus. Tiap siklus terdiri dari tiga kali pertemuan yang dilaksanakan berdasarkan prosedur yang telah ditentukan. Dalam proses pembelajaran yang dilaksanakan pada pembelajaran prasiklus, guru masih menggunkan metode ceramah di depan kelas. Hal ini berdampak pada hasil menulis karangan narasi siswa kelas V SDN Pulorejo 01 Pati masih belum sesuai dengan yang diharapkan.

Berdasarkan penelitian prasiklus, hasil menulis karangan narasi siswa masih kurang dengan memperoleh nilai rata-rata atau masih di bawah kriteria ketuntasan minimal yang telah ditentukan yaitu 75 dan siswa yang tuntas belum mencapai $\geq$ 
$80 \%$ dari jumlah siswa kelas $\mathrm{V}$ (sesuai indikator keberhasilan). Ketuntasan belajar yang diperoleh siswa prasiklus adalah 39\% dengan jumlah siswa yang tuntas sebanyak 9 siswa. Oleh karena itu, perlu adanya variasi metode pembelajaran yang tepat untuk menarik siswa agar lebih semangat dalam belajar yaitu dengan penggunaan mind mapping.

Pada siklus I diterapkan metode pembelajaran mind mapping tentang menulis karangan narasi. Pelaksanaan pembelajaran siklus I berlangsung dengan baik, kondisi siswa sudah cukup kondusif walaupun masih ada satu dua siswa yang masih suka bergurau sendiri. Dalam proses pembelajaran yang diberikan dengan menggunakan penerapan metode pembelajaran mind mapping, siswa sangat tertarik dan antusias dengan metode yang diberikan dan siswa sudah mulai saling berbagi dengan temanteman yang lainnya. Ketuntasan evaluasi belajar siklus 1 yang diperoleh adalah $43 \%$ dengan jumlah siswa yang tuntas sebanyak 10 siswa dari total 23 siswa dengan nilai terendah 60 , nilai tertinggi 90 , dan nilai rata-rata kelas 73,48.

Berdasarkan refleksi pada siklus I yang masih terdapat kekurangan dalam penerapan metode pembelajaran mind mapping, maka akan direncanakan penelitian tindakan kelas pada siklus II guna memperbaiki kekurangan-kekurangan yang ada pada siklus I. Perbaikan dilakukan pada siklus II dengan cara menambahkan gambar dengan kata kunci yang sudah ditentukan pada saat penerapan metode mind mapping.

Proses pembelajaran yang dilaksanakan pada siklus II ini siswa sangat bersemangat. Siswa lebih antusias dengan ditambahnya kata kunci, sehingga saat siswa membuat cerita karangan narasi siswa sudahmempunyai gambaranyang lebih memudahkan mereka dalam menuangkan ide mereka ke dalam tulisan. Pada siklus II ini hasil menulis karangan narasi siswa mengalami peningkatan jumlah siswa yang tuntas belajar sebanyak 19 siswa dari total 23 siswa dengan nilai terendah 65 , dan nilai tertinggi 95, dan nilai rata-rata kelas 80,65.

Tabel 1 Nilai rata-rata Hasil Karangan Narasi Siswa

\begin{tabular}{ccc}
\hline Tahap & Rata-rata & Persentase Ketuntasan (\%) \\
\hline Prasiklus & 68,43 & 39 \\
Siklus I & 78,04 & 43 \\
Siklus II & 80,65 & 83 \\
\hline
\end{tabular}

Secara umum terjadi peningkatan skor dari prasiklus ke siklus I dan siklus II. Hal tersebut sebagaimana disajikan pada Tabel 1. Nilai ratarata kelas yang lebih dari KKM dapat dilihat sejak digunakan metode mind mapping yaitu dilaksanakan mulai siklus I dan dilanjutkan ke siklus II. Adapun peningkatan dari prasiklus ke siklus I sebesar 4\% kemudian meningkatkan kembali sebesar 44\% pada siklus II. Terlebih lagi, peningkatan signifikan ditunjukkan dengan persentase ketuntasan yang meningkat hingga sebesar $83 \%$ pada akhir siklus II. Hasil penelitian ini selanjutnya dibahas secara rinci pada bagian pembahasan.

\section{PEMBAHASAN}

Penelitian tindakan kelas ini dilaksanakan dalam dua siklus. Tiap siklus terdiri dari tiga kali pertemuan yang dilaksanakan berdasarkan prosedur yang telah ditentukan. Dalam proses pembelajaran yang dilaksanakan pada pembelajaran prasiklus, guru masih menggunakan metode ceramah di depan kelas. Pembelajaran ini membuat siswa bosan sehingga siswa kurang memperhatikan guru saat menjelaskan materi, siswa kurang aktif, dan kebanyakan siswa tidak tertarik kemudian menjadikan siswa bercanda sendiri. Dampak dari penerapan metode ceramah ini sejalan dengan Suherman (2008) yang menyebutkan metode ceramah lebih didominasi guru dan kurang memperhatikan siswa. Hal ini berimplikasi pada hasil menulis karangan narasi siswa kelas V SDN Pulorejo 01 Pati yang masih belum sesuai dengan yang diharapkan sebagaimana data ketuntasan yang hanya berada di angka $39 \%$.

Sebagai upaya peningkatan pembelajaran bahasa Indonesia tentang menulis karangan narasi maka diperlukan variasi pembelajaran yang menarik perhatian siswa agar tidak bosan dengan pembelajaran yang akan disampaikan. Variasi yang dipilih adalah metode mind mapping (Sulistiyaningsih, 2010; Dewi, 2010). Metode mind mapping dipilih karena di dalam metode pembelajaran tersebut berusaha mengajarkan siswa untuk membuat sebuah kalimat dengan beberapa kata kunci yang telah disediakan agar bisa menangkap konsep, bisa mengembangkan kata kunci menjadi kalimat yang baik dan membedakannya dengan kalimat-kalimat lain.

Pada proses penelitian siklus I, diterapkan metode pembelajaran mind mapping tentang menulis karangan narasi. Pelaksanaan pembelajaran siklus I berlangsung dengan baik, kondisi siswa sudah cukup kondusif walaupun masih ada satu dua siswa 
yang masih suka bergurau sendiri. Dalam proses pembelajaran yang diberikan dengan menggunakan penerapan metode pembelajaran mind mapping, siswa sangat tertarik dan antusias dengan metode yang diberikan. Siswa sudah mulai saling berbagi dengan teman-teman yang lainnya.

Adapun kekurangan pelaksanaan di siklus I dalam penerapan metode pembelajaran mind mapping yaitu metode pembelajaran yang diberikan belum pernah diterapkan pada siswa kelas $\mathrm{V}$ sebelumnya, sehingga membuat siswa masih terlihat bingung yang dibuktikan dengan ketuntasan evaluasi belajar siklus 1 hanya mencapai $43 \%$.

Berdasarkan refleksi pada siklus I yang masih terdapat kekurangan dalam penerapan metode pembelajaran mind mapping, maka dilakukan perbaikan dilakukan pada siklus II dengan cara menambahkan gambar dengan kata kunci yang sudah ditentukan pada saat penerapan metode mind mapping. Proses pembelajaran yang dilaksanakan pada siklus II ini menunjukkan siswa lebih antusias dengan ditambahnya kata kunci. Siswa membuat karangan narasi dengan mempunyai gambaran yang lebih memudahkan mereka dalam menuangkan ide mereka ke dalam tulisan. Pada siklus II ini hasil menulis karangan narasi siswa mengalami peningkatan $83 \%$ dan hasil meningkat dari siklus 1 ke siklus 2 menjadi 80,65.

Refleksi tindakan siklus II didasarkan data peningkatan keterampilan membuat karangan narasi dari tahap prasiklus sampai siklus II. Hal ini membuktikan bahwa penerapan metode mind mapping dapat meningkatakan keterampi-lan membuat karangan narasi dan sudah sesuai dengan kriteria ketuntasan ideal yang harus dicapai adalah lebih dari $80 \%$. Sehingga dapat dikatakan bahwa ketuntasan belajar telah tercapai. Hal ini ditunjukan dengan jumlah ketuntasan siswa yang tuntas belajar pada siklus II yang mencapai $83 \%$. Terdapat siswa yang pada awal pembelajaran (prasiklus) mendapat hasil yang sangat tidak memuaskan kemudian pada ujian siklus I dan siklus II mendapat hasil yang baik dan perbaikan nilainya sangat tajam. Oleh sebab itu, penelitian ini hanya menggunakan dua siklus. Adapun secara spesifik, pada siklus II indikator keberhasilannya sudah terpenuhi, yaitu $80 \%$ siswa tuntas belajar atau mendapat hasil di atas KKM sebesar 75 sehingga tidak dilanjutkan ke siklus berikutnya.

Berdasarkan uraian di atas dapat disimpulkan bahwa pembelajaran dengan menggunakan me- tode mind mapping efektif dalam meningkatkan keterampilan menulis karangan narasi siswa. Hasil ini didukung oleh Arini (2012) yang menunjukkan bahwa peta pikiran (mind mapping) mampu meningkatkan keterampilan menulis deskripsi siswa. Buzan, dkk., (2010) menyatakan bahwa cara mudah menggali informasi dari dalam dan dari luar otak yang tampak seperti cabang-cabang pohon. Terlebih lagi, secara signifikan mind mappning terbukti dapat meningkatkan proses berpikir siswa sehingga lebih munah menghubungkan ide satu dan lainnya dalam sebuah karangan narasi (Subandi, dkk., 2018). Hal serupa juga disampaikan oleh Sulistiyaningsih (2010) dan Dewi (2010) bahwa metode mind mapping memiliki kelebihan yaitu mempermudah siswa dalam mengembangkan sebuah kata menjadi kalimat yang baik dan membuat siswa menjadi antusias dalam pembelajaran. Kelemahannya yaitu jika siswa belum terbiasa akan metode mind mapping akan membingungkan siswa. Metode ini juga bisa membuat siswa lebih kompak dan saling menghargai, semua itu berdampak pada hasil belajar siswa dalam mengasah keterampilan menulis siswa.

Hasil penelitian ini tidak hanya memberikan kontribusi pada hasil belajar tetapi juga proses pembelajaran yang berlangsung. Secara umum, mind mapping juga membantu guru dalam mengelola kelas selama pembelajaran berlangsung. Hal ini dikarenakan siswa lebih tertarik karena pada metode mind mapping secara tidak langsung mempergunakan cabang-cabang yang berisi kata kunci yang mampu menarik minat siswa dalam kegiatan belajar, serta dapat mendukung dan membantu penyerapan siswa aktif selama proses pembelajaran berlangsung. Metode ini juga mampu membantu siswa menjadi lebih aktif, serta mengatur dan memprioritaskan materi belajar dengan lebih baik (Aini, dkk., 2012).

\section{SIMPULAN DAN SARAN}

\section{Simpulan}

Berdasarkan hasil penelitian dan pembahasan dalam penelitian ini dapat disimpulkan bahwa dengan penggunaan metode mind mapping dapat meningkatkan keterampilan menulis karangan narasi siswa kelas V di SD Negeri Pulorejo 01 Pati. Hal tersebut ditunjukan dari kondisi awal sampai pada pelaksanaan siklus I dan siklus II mengalami peningkatan signifikan. Hasil evaluasi keterampilan 
menulis karangan narasi pada prasiklus adalah sebanyak 9 (39\%) siswa mencapai KKM. Adapun hasil belajar pada siklus I mencapai KKM meningkat menjadi $43 \%$ dengan ketuntasan sebanyak 10 siswa mencapai KKM. Hasil selanjutnya yaitu pada siklus II yang menunjukkan bahwa hasil belajar siswa meningkat menjadi 83\% siswa mencapai KKM (19 dari 23 siswa tuntas). Secara umum, hasil tersebut menggambarkan signifikansi peningkatan hasil belajar siswa dalam keterampilan menulis narasi.

\section{Saran}

Terdapat beberapa saran yang didasarkan hasil penelitian ini. Pertama, terkait dengan metode pembelajaran, sebaiknya guru lebih bervariasi dalam penggunaan metode dan tidak hanya menggunakan metode ceramah saja. Dalam hal ini penggunaan metode mind mapping dapat dijadikan alternatif dan solusi untuk meningkatkan hasil pembelajaran karangan narasi siswa. Kedua, untuk menunjang hasil penelitian sejenis, dapat dilakukan penelitian lanjutan yang lebih mendalam terutama dalam peningkatan keterampilan naratif siswa dengan menggunakan mind mapping.

\section{DAFTAR RUJUKAN}

Aini, A., Andayani, A., \& Anindyarini, A. (2012). Metode Mind Mapping untuk Meningkatkan Keterampilan Berbicara Siswa Sekolah Dasar. BASASTRA, 1(1), 35-45.

Arikunto, S. (2010). Dasar-Dasar Evaluasi Pendidikan. Jakarta: PT Bumi Aksara.

Arikunto, S., Suhardjono \& Supardi.(2012). Penelitian Tindakan Kelas. Jakarta: PT. Bumi Aksara.

Arini, N. W. (2012). Implementasi Metode Peta Pikiran Berbantuan Objek Langsung untuk Meningkatkan Keterampilan Menulis Deskripsi. Jurnal Pendidikan dan Pengajaran, 45(1), 66-74.

Buzan, T., Buzan, B., \& Harrison, J. (2010). The Mind Map Book: Unlock Your Creativity, Boost Your Memory, Change Your Life. New York: Pearson BBC Active.

Dewi, S. P. (2010). Penerapan Metode Peta Pikiran (Mind Mapping) untuk Meningkatkan Keterampilan Menulis Narasi Pada Siswa Kelas IV SD Negeri I Trirenggo Bantul Yogyakarta Tahun Ajaran 2009/2010. Disertasi tidak diterbitkan. Surakarta: Universitas Sebelas Maret.
Huy, N. T. (2015). Problems affecting learning writing skill of grade 11 at Thong Linh High School. Asian Journal of Educational Research, 3(2), 53-69.

Keraf. (2010). Argumentasi dan Narasi. Jakarta: PT Gramedia Pustaka Utama.

Kurniawati, D. D. (2010). Pengaruh Metode Mind Mapping dan Keaktifan Belajar Siswa Terhadap Prestasi Belajar Ilmu Pengetahuan Sosial Pada Siswa Kelas VIII Sekolah Menengah Pertama Muhammadiyah 5 Surakarta Tahun Pelajaran 2009/2010. Disertasi tidak diterbitkan. Surakarta: Universitas Muhammadiyah Surakarta.

Martavia, R. F., Thahar, H. E., \& Asri, Y. (2016). Hubungan Minat Baca dengan Keterampilan Menulis Narasi Ekspositoris Siswa Kelas VII SMP Negeri 11 Padang. Pendidikan Bahasa dan Sastra Indonesia, 5(2), 363-369.

Permendiknas Nomor 22 Tahun 2006 Tentang Standar Isi. (2006). Jakarta: Depdiknas.

Permendiknas Nomor 41 Tahun 2007 tentang Standar Proses untuk Satuan Pendidikan Dasar dan Menengah. (2007). Jakarta: Depdiknas.

Subandi, Chizuru, S., Yoshinori, K., \& Wibisono, G. (2018). The Implementation of Mind Mapping Technique to Improve Mandarin Students' Systematic Thinking Skills. In 2nd Social Sciences, Humanities and Education Conference: Establishing Identities through Language, Culture, and Education (SOSHEC 2018). Atlantis Press.

Suherman, E. (2008). Model belajar dan pembelajaran berorientasi kompetensi siswa. Educare, 5(2).

Sulistiyaningsih, E. (2010). Peningkatan Kemampuan Menulis Narasi dengan Metode Peta Pikiran (Mind Mapping) pada Siswa Kelas V SD Negeri Karangasem III Surakarta Tahun Pelajaran 2010/2011. Disertasi tidak diterbitkan. Surakarta: Universitas Sebelas Maret.

Tarigan, H. G. (2008). Menulis Sebagai Keterampilan Berbahasa. Bandung: Angkasa.

Undang-Undang RI No. 20 Tahun 2003 tentang Sistem Pendidikan Nasional. (2003)

Yunus, M. M., \& Chien, C. H. (2016). The use of mind mapping strategy in Malaysian university English test (MUET) Writing. Creative Education, 7(04), 619. 